\title{
PENGENALAN PUBLIC SPEAKING DI SMP KATOLIK ABDI SISWA II JAKARTA BARAT
}

\author{
R. Oktavianti ${ }^{1}$, S. Paramita ${ }^{2}$
}

\begin{abstract}
ABSTRAK
Berbicara di depan umum atau public speaking masih menjadi kekhawatiran bagi orang dewasa maupun siswa sekolah. Kemampuan ini seringkali belum diasah sepenuhnya ketika duduk di bangku sekolah. Sementara, dengan memiliki keterampilan public speaking yang baik, mampu mengembangkan wawasan sekaligus kepribadian para siswa. Keterampilan ini juga dibutuhkan dalam dunia kerja. Public speaking merupakan salah satu materi yang diajarkan di Fakultas Ilmu Komunikasi Universitas Tarumanagara. Dengan persoalan kendala dalam melakukan public speaking, pengalaman dan kepakaran tim pengabdian masyarakat, maka diadakan pengenalan sekaligus praktik public speaking kepada para siswa SMP Katolik Abdi Siswa II Jakarta Barat. Tim pengabdian kepada masyarakat berupaya mengenalkan public speaking kepada siswa-siswi SMP dengan materi yang mudah dipahami dan juga relevan dengan kondisi saat ini. Tujuan kegiatan ini adalah membantu para siswa dalam berlatih melakukan public speaking. Kegiatan pengenalan ini telah mampu meningkatkan pemahaman tentang pentingnya public speaking, pentingnya berlatih public speaking, hingga mengidentifikasi kekhawatiran para siswa dalam melakukan public speaking.
\end{abstract}

Kata kunci : public speaking, ilmu komunikasi, SMP Katolik Abdi Siswa II

\begin{abstract}
Public speaking is concern for both adults and teenager. This subject is often not fully developed in a school yet. Meanwhile, by having good public speaking skills, students are able to develop their insights as well as their personalities. These skills are also needed in their future work. Public speaking is one of subject learned at Fakultas Ilmu Komunikasi Universitas Tarumanagara. Facing those problem above, the experience and expertise of the community service team, we held an introduction as well as public speaking practice to students of SMP Katolik Abdi Siswa II in West Jakarta. The community service team attempted to introduce public speaking to students with the easy way and also relevant to students. The purpose of this activity is to help students practice public speaking. This community service activity has been able to increase students understanding of the importance of public speaking, the importance of practicing public speaking, then identify students' obstacles in conducting public speaking.
\end{abstract}

Keywords: public speaking, communication studies, SMP Katolik Abdi Siswa II

\section{PENDAHULUAN}

Berbicara di depan umum (public speaking) bukan hal yang mudah bagi sebagian orang. Seringkali orang yang hebat dan pandai dalam satu bidang, menjadi tidak percaya diri ketika tampil di depan publik (Adha, 2016). Hal itu pula yang dialami Larry King, seorang pembawa acara televisi

\footnotetext{
${ }^{1}$ Dosen Fakultas Ilmu Komunikasi Universitas Tarumanagara, roswitao@ fikom.untar.ac.id

${ }^{2}$ Dosen Fakultas Ilmu Komunikasi Universitas Tarumanagara, sintap@fikom.untar.ac.id
} 


\section{R. Oktavianti, S. Paramita}

terkenal di AS ketika menghadapi berbagai narasumber yang ahli dalam bidangnya masing-masing (King, 2007).

Dalam jajak pendapat Gallup kepada warga AS tahun 2001 menemukan bahwa ketakutan berbicara di depan umum menduduki ketakutan kedua, setelah takut pada ular besar. Sekitar 95 persen penutur/pembicara (speakers) dewasa mengalami beberapa tingkat kecemasan dan 20 persen siswa mengalami kecemasan berbicara di depan umum (Hamilton, 2012).

Sebuah survei yang dilakukan kepada 815 siswa tahun 2012 menunjukkan empat hal yang menjadi ketakutan utama para siswa yakni berbicara di depan publik (public speaking), masalah keuangan, kematian, dan kesepian. Survei ini hampir sama dengan hasil survei yang dilakukan oleh R. H. Bruskin Associate tahun 1973. Dengan sampel orang dewasa yakni dalam kisaran usia 40 tahun, menunjukkan bahwa berbicara di depan kelompok, ketinggian, serangga, dan masalah keuangan menduduki empat teratas ketakutan yang dihadapi dalam hidup warga AS (Dwyer \& Davidson, 2012). Hal yang sama ditunjukkan dalam survei dari The People's Almanack Book of List oleh David Wallechinsky, hal yang paling ditakuti adalah berbicara di depan kelompok (Yawang, 2016).

Public speaking merupakan salah satu bentuk komunikasi interpersonal atau komunikasi antarpribadi. Komunikasi antarpribadi adalah interaksi verbal dan nonverbal antara dua (atau kadang lebih dari dua) orang yang saling tergantung. Pesan verbal yang dilibatkan yaitu katakata/ucapan, teks, foto, dan video. Sementara pesan nonverbal dalam interaksi tatap muka yaitu ekspresi wajah, kontak mata, postur tubuh, cara berbusana, dsb (DeVito, 2013). Dengan demikian, public speaking merupakan rumpun dari Ilmu Komunikasi.

Public speaking dipraktikkan dalam bentuk pidato, ceramah, orasi, presentasi, menjadi pemateri diskusi, mengajar di kelas, memberikan briefing, memandu acara, dan memimpin atau berbicara dalam rapat (Putri, 2017). Dalam hal ini, public speaking menjadi sarana penting keterlibatan masyarakat. Dengan berbicara di depan publik, seorang pembicara bisa mengekspresikan ide-ide yang berdampak pada isu-isu penting di masyarakat. Berbicara di depan umum memberi kesempatan bagi pembicara untuk membuat perbedaan terhadap sesuatu yang menjadi kepeduliannya (Lucas, 2015).

Atas dasar itulah kegiatan pengabdian kepada masyarakat dalam bentuk pengenalan dan praktik public speaking ini dilakukan. Tujuannya untuk mengenalkan public speaking, menunjukkan cara dalam melakukan public speaking yang baik, hingga membangun kepercayaan diri dalam melakukan public speaking.

\section{METODE PELAKSANAAN}

\subsection{Tahap persiapan}

Tim pengabdi melakukan studi pustaka untuk mengetahui persoalan siswa sekolah menengah di bidang Ilmu Komunikasi, sesuai dengan bidang kepakaran tim pengabdi. Setelah masalah dipetakan, tim pengabdi memilih sekolah dengan radius $<200 \mathrm{~km}$ dari Universitas Tarumanagara. Tim pengabdi memilih SMP Katolik Abdi Siswa II yang terletak di Komp. Perumahan Taman Aries, Blok E9 No. 1. Kembangan, Jakarta 11620 atau berjarak 4,5 km dari perguruan tinggi tim pengabdi. Tim pengabdi menghubungi Kepala Sekolah SMP Katolik Abdi Siswa II, Bapak Antonius Mardiyono untuk meminta kesediaan menjadi mitra pengabdian masyarakat. Pihak sekolah menyediakan waktu kegiatan pengenalan dan praktik public speaking setelah siswa-siswi selesai ujian akhir semester yakni pada tanggal 13 Desember 2018.

\subsection{Tahap pelaksanaan}


Kegiatan Pengabdian Kepada Masyarakat berlangsung dari pukul 07.00 hingga pukul 12.00 WIB. Kegiatan berlangsung selama dua sesi. Sesi pertama berupa pemberian materi melalui presentasi dan permainan. Sesi kedua berupa praktik menulis naskah dan public speaking.

\subsection{Tahap evaluasi dan pelaporan}

Tim pengabdi melakukan evaluasi dengan kepala sekolah setelah kegiatan. Evaluasi juga dilakukan dengan membagikan angket/ kuisioner kepada para siswa. Hasil angket tersebut diolah sebagai bahan laporan akhir kegiatan, publikasi, dan bahan ajar.

\section{HASIL DAN PEMBAHASAN}

\subsection{Pengenalan dan praktik public speaking}

Pengenalan Ilmu Komunikasi pada sesi pertama, dimulai dengan pemberian materi "How to be a Great Speaker". Materi ini menjelaskan tentang makna public speaking, kendala dalam melakukan public speaking, cara mengatasi kendala tersebut, cara-cara mengembangkan kepercayaan diri, hingga penampilan seorang public speaker yang baik. Saat pemberian materi, agar siswa-siswi tidak jenuh, tim memberikan sejumlah permainan berhadiah seputar materi yang sudah dijelaskan. Pemberian materi dan permainan ini berlangsung hingga pukul 09.10 WIB.

Pada sesi kedua pukul 09.40 WIB, para siswa melakukan public speaking. Namun sebelum praktik, tim memberikan materi tentang cara menyusun naskah public speaking. Para siswa menonton video dan memberikan pandangan/tanggapan mengenai video tersebut. Tanggapan tersebut ditulis dalam bentuk naskah public speaking dan dibacakan di depan siswa lain.

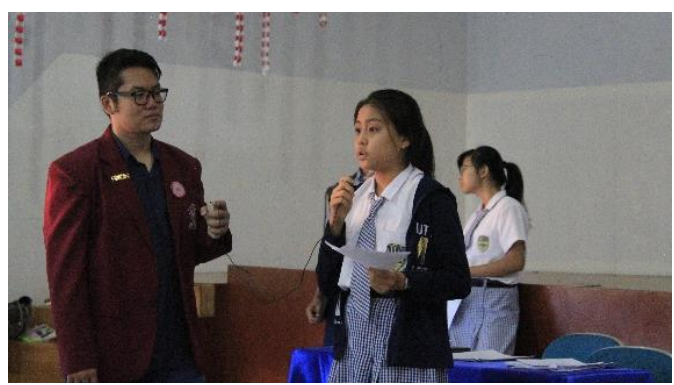

Gambar 3.1. Salah satu siswi melakukan praktik public speaking

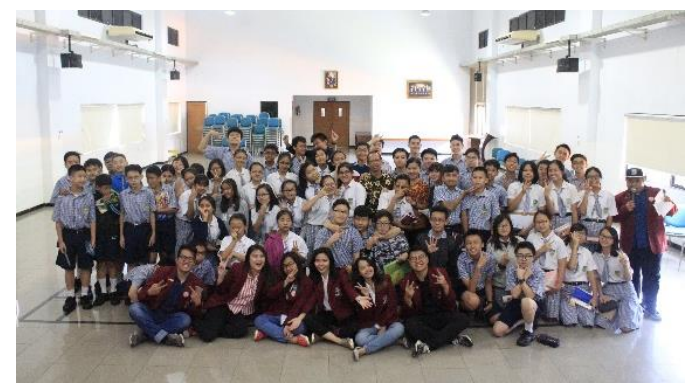

Gambar 3.2. Peserta kegiatan pengabdian kepada masyarakat pengenalan dan praktik public speaking

\subsection{Pembahasan}


Dari 63 siswa yang hadir, seluruh siswa mengisi kuisioner terdiri atas 30 siswa laki-laki dan 33 siswa perempuan.

Tabel 1.1. Hasil kuisioner sebelum dan setelah pengenalan dan praktik public speaking

\begin{tabular}{|c|c|c|c|}
\hline No. & & Frekuensi & Persentase \\
\hline \multirow[t]{3}{*}{1} & $\begin{array}{l}\text { Sebelum kegiatan pengabdian, } \\
\text { pernah mendengar tentang "Public } \\
\text { Speaking" }\end{array}$ & & \\
\hline & Ya & 50 & 79,4 \\
\hline & Tidak & 13 & 20,6 \\
\hline \multirow[t]{3}{*}{2} & $\begin{array}{lrr}\text { Sebelum kegiatan } & \text { pengabdian, } \\
\text { mengetahui } & \text { Public } & \text { Speaking } \\
\text { diajarkan di jurusan } & \text { Ilmu } \\
\text { Komunikasi } & & \\
\end{array}$ & & \\
\hline & Ya & 42 & 66,7 \\
\hline & Tidak & 11 & 33,3 \\
\hline \multirow[t]{3}{*}{3} & $\begin{array}{l}\text { Setelah kegiatan pengabdian, } \\
\text { keterampilan Public } \\
\text { penting bagi siswa }\end{array}$ & & \\
\hline & $\mathrm{Ya}$ & 60 & 95,2 \\
\hline & Tidak & 3 & 4,8 \\
\hline \multirow[t]{3}{*}{4} & $\begin{array}{l}\text { Setelah kegiatan pengabdian, } \\
\text { keterampilan Public Speaking perlu } \\
\text { dilatih sejak dini }\end{array}$ & & \\
\hline & Ya & 63 & 100 \\
\hline & Tidak & 0 & 0 \\
\hline
\end{tabular}

Tabel 1.2. Pernah berbicara di depan umum

\begin{tabular}{|c|c|c|}
\hline & Frekuensi & Persentase \\
\hline Ya & 56 & 88,9 \\
\hline Tidak & 7 & 11,1 \\
\hline
\end{tabular}

Tabel 1.3. Pertama kali berbicara di depan umum

\begin{tabular}{|c|c|c|}
\hline Usia & Frekuensi & Persentase \\
\hline$<5$ & 3 & 5,3 \\
\hline $6-7$ & 3 & 5,3 \\
\hline $8-9$ & 10 & 18,0 \\
\hline $10-11$ & 28 & 50,0 \\
\hline $12-13$ & 11 & 19,6 \\
\hline 14 & 1 & 1,8 \\
\hline Total & 56 & 100 \\
\hline
\end{tabular}

Tabel 1.4. Paling berjasa dalam mengajarkan public speaking

\begin{tabular}{|c|c|c|}
\hline & Frekuensi & Persentase \\
\hline Guru & 44 & 78,6 \\
\hline Orangtua & 5 & 8,9 \\
\hline Kakak/Adik & 1 & 1,8 \\
\hline Teman & 0 & 0,0 \\
\hline Lainnya & 6 & 10,7 \\
\hline Total & 56 & 100 \\
\hline
\end{tabular}

Tabel 1.4. Kegiatan/Acara Mempraktikkan Kemampuan Public Speaking

\begin{tabular}{|c|c|c|}
\hline & Frekuensi & Persentase \\
\hline Mata pelajaran/tugas di kelas & 44 & 78,6 \\
\hline Acara di sekolah & 9 & 16,0 \\
\hline
\end{tabular}




\begin{tabular}{|c|c|c|}
\hline Acara di tempat ibadah & 0 & 0 \\
\hline Acara di rumah & 0 & 0 \\
\hline Lainnya & 3 & 5,4 \\
\hline Total & 56 & 100 \\
\hline
\end{tabular}

Sebelum kegiatan pengabdian kepada masyarakat, masih ada siswa yang belum pernah mendengar kata public speaking (Tabel 1). Sebanyak $88,9 \%$ siswa menyatakan sudah pernah berbicara di depan umum (Tabel 2). Artinya kata 'public speaking' belum familiar di kalangan para siswa SMP. Bahkan sebanyak 33,3 persen tidak tahu bahwa public speaking diajarkan di perguruan tinggi jurusan Ilmu Komunikasi (Tabel 1).

Lebih dari 50 persen siswa pertama kali bicara di depan umum pada usia 10 - 11 tahun, yakni pada saat duduk di bangku kelas V dan VI Sekolah Dasar (Tabel 3). Para siswa mempraktikkan public speaking dalam mata pelajaran di kelas (Tabel 5) dengan guru sebagai orang yang paling berjasa dalam mengajarkan public speaking (Tabel 4).

Meski duduk di bangku SMP, masih ada 11,1 persen siswa yang belum pernah berbicara di depan umum (Tabel 2). Dari pertanyaan terbuka kepada seluruh siswa, para siswa menyebut kendala utama melakukan public speaking yakni ketakutan atau kekhawatiran (takut salah, ditertawakan, hingga diejek), yang kemudian berpengaruh terhadap perasaan dan bahasa tubuh (gugup, grogi, dan gemetar), sifat malu karena tidak suka tampil atau dilihat banyak orang, tidak percaya diri, hingga kurang latihan (ketiadaan guru/pendamping dan tidak menguasai bahan). Oleh karena itu, setelah kegiatan pengabdian kepada masyarakat, para siswa menilai public speaking itu penting untuk dipelajari dan dilatih dilatih sejak dini (Tabel 1).

\section{KESIMPULAN DAN SARAN}

Sebagian besar siswa sekolah lanjutan sudah dibekali ilmu terkait public speaking sejak duduk di bangku akhir sekolah dasar. Namun, penyaluran ilmu tersebut belum disertai dengan praktik sehingga sebagian besar masih menemui kendala saat berbicara di depan publik. Ketakutan yang kemudian berefek pada bahasa tubuh, sifat pemalu, kurang percaya diri, hingga kurang berlatih menjadi kendala utama dalam melakukan public speaking.

Kegiatan pengabdian kepada masyarakat berupa pengenalan hingga praktik ini telah mampu memberi pemahaman para siswa tentang pentingnya berlatih public speaking sejak dini, serta membantu meningkatkan kepercayaan diri para siswa dengan praktik public speaking. Kegiatan pengabdian kepada masyarakat tentang public speaking berikutnya bisa dilakukan kepada guru mengingat para siswa menilai guru dan mata pelajaran di kelas menjadi instrumen pembelajaran public speaking yang paling utama.

\section{UCAPAN TERIMA KASIH}

Tim Pengabdian Masyarakat Fakultas Ilmu Komunikasi Universitas Tarumanagara mengucapkan terimakasih kepada Direktorat Penelitian dan Pengabdian Kepada Masyarakat Universitas Tarumanagara atas dukungan dana sehingga kegiatan ini bisa berjalan dengan lancar. Ucapan terimakasih juga disampaikan kepada kepala sekolah, para guru, dan siswa-siswi SMP Katolik Abdi Siswa II Jakarta Barat, sebagai mitra kegiatan pengabdian kepada masyarakat.

\section{DAFTAR PUSTAKA}


Adha, K. (2016). Panduan Mudah Public Speaking Edisi Revisi. Yogyakarta: Komunika.

DeVito, J. A. (2013). The Interpersonal Communication Book Thirteenth Edition. New York: Pearson.

Dwyer, K., \& Davidson, M. (2012). Is Public Speaking Really More Feared Than Death? Communication Research Reports, 29(2), 99-107. doi:10.1080/08824096.2012.667772

Hamilton, C. (2012). Essentials of Public Speaking Fifth Edition. Boston, MA: Wadsworth Cengage Learning.

King, L. (2007). Seni Berbicara Kepada Siapa Saja Kapan Saja Di mana Saja. Jakarta: Gramedia Pustaka Utama.

Lucas, S. E. (2015). The Art of Public Speaking Twelfth Edition. New York: McGraw Hill Education.

Putri, D. V. (2017). Lancar Pidato \& Public Speaking Tanpa Grogi, Tanpa Panik. Yogyakarta: Komunika.

Yawang, H. A. (2016, 55 5). https://muda.kompas.id/2016/08/02/public-speaking-berdiri-tegakdan-berbicara-sebaik-berpikir/. Dipetik 1 2, 2019, dari https://muda.kompas.id. 